\title{
Pelatihan Pengkajian Nyeri sebagai Upaya Mengoptimalkan Manajemen Nyeri di Rumah Sakit Universitas Brawijaya
}

\author{
Training of Pain Valuation as an Effort to Optimize Pain Management at Universitas Brawijaya \\ Hospital
}

\author{
Efris Kartika Sari ${ }^{1 *}$, Alfrina Hany ${ }^{1}$, Rustiana Tasya Ariningpraja ${ }^{1}$ \\ ${ }^{1}$ Fakultas Kedokteran Universitas Brawijaya Malang \\ *efriskartika@ub.ac.id
}

\begin{abstract}
ABSTRAK
Manajemen nyeri yang optimal merupakan salah satu upaya penting dalam lingkup layanan Rumah Sakit. Nyeri yang tidak tertangani dengan baik dapat menyebabkan masalah tambahan bahkan memperlambat perbaikan kondisi pasien. Perawat merupakan petugas kesehatan yang harus mampu dalam mendukung upaya tersebut. Pengkajian nyeri yang tepat akan menjadi dasar manajemen nyeri yang optimal pada pasien. Kegiatan pengabdian masyarakat ini bertujuan untuk meningkatkan kemampuan perawat dalam melakukan pengkajian nyeri pada pasien komunikatif maupun dengan gangguan komunikasi, sehingga sehingga perawat dapat melakukan pengkajian nyeri secara tepat, rutin, dan terstruktur. Hal ini diwujudkan dengan melatih perawat dengan berbagai teori tentang pengkajian nyeri, terutama penggunaan skala nyeri dengan berbagai kelebihan dan kekurangan masing-masing dan penerapan penggunaan skala nyeri tersebut. Kegiatan dilaksanakan di Rumah Sakit Universitas Brawijaya, Kota Malang pada November-Desember Tahun 2019. Metode kegiatan yang dilakukan terdiri dari: focus group discussion, pre-test dan post-test, dan pemberian materi. Hasil kegiatan menunjukkan bahwa pelatihan pengkajian nyeri ini dapat meningkatkan pengetahuan perawat tentang pengkajian nyeri. Berdasarkan hasil tersebut dapat disimpulkan bahwa pelatihan pengkajian nyeri pada perawat perlu dilakukan secara berkesinambungan untuk mendukung upaya manajemen nyeri yang optimal.
\end{abstract}

Kata kunci - Pelatihan Pengkajian nyeri; Manajemen nyeri; Pengetahuan Perawat

\begin{abstract}
Optimum pain management is one of the important efforts in the scope of Hospital services. Unhandled pain can cause additional problems and even slow down the improvement of the patient's condition. Nurses as a health worker must be able to support these efforts. Proper assessment of pain will be the basis for optimal pain management. This community service activity aims to improve the ability of nurses in assessing pain in communicative and communication disorders patients, so that nurses can conduct pain assessments appropriately, routinely, and in a structured manner. This is realized by training nurses with various theories about pain assessment, especially the use of pain scales with various advantages and disadvantages of each and the application of pain scales. The activity was carried out at Universitas Brawijaya Hospital, Malang City in November-December 2019. The method of activities carried out consisted of: focus group discussions, pre-test and post-test, and material delivery. The results of the activities show that this pain assessment training can increase nurses' knowledge about pain assessment. Based on these results it can be concluded that the pain assessment training for nurses needs to be done continuously to support optimal pain management.
\end{abstract}

Keywords - Pain assessment training, Pain management, Nurses' knowledge 


\section{Pendahuluan}

Selama berabad-abad, nyeri telah menjadi alasan utama pasien mencari pelayanan kesehatan ${ }^{1}$. IASP atau International Association for the Study of Pain mendefinisikan nyeri sebagai "pengalaman indrawi dan emosional yang tidak menyenangkan terkait dengan kerusakan jaringan aktual mapupun potensial, atau dijelaskan dalam hal kerusakan tersebut" (www.iasp-pain.org). Nyeri selalu merupakan pengalaman subyektif, pribadi, dan tidak menyenangkan ${ }^{1}$. Nyeri yang tidak tertangani dengan baik dapat mengakibatkan efek yang tidak diinginkan. Baratta et al (2014) ${ }^{2}$ Nyeri yang dialami pasien seperti nyeri pasca operasi yang tidak terkontrol dapat mengakibatkan konsekuensi klinis, psikologis, dan sosial ekonomi yang signifikan ${ }^{2}$. Manajemen nyeri yang tidak adekuat dapat menghasilkan peningkatan morbiditas dan mortalitas, juga dapat menunda pemulihan, menurunkan kepuasan pasien, dan mengarah pada nyeri kronis $^{2}$.

Di Indonesia, pasal 43 ayat 1 UndangUndang No. 44 Tahun 2009 tentang Rumah Sakit mendukung patient safety di Rumah Sakit. Rumah Sakit harus memberikan pelayanan pasien yang lebih aman, termasuk di dalamnya asesmen risiko, identifikasi, dan manajemen risiko terhadap pasien, pelaporan dan analisis insiden, kemampuan untuk belajar dan menindaklanjuti insiden, dan menerapkan solusi untuk mengurangi serta meminimalkan timbulnya risiko. Sistem pada Hospital patient safety diharapkan dapat mencegah terjadinya harm/cedera yang mencakup pengalaman tidak menyenangkan diantaranya berupa nyeri ${ }^{3}$. Upaya pencegahan pasien dari nyeri tersebut yaitu dilakukan manajemen nyeri sebagai bagian dari penatalaksanaan pasien di Rumah Sakit. Meskipun manajemen nyeri merupakan prioritas perawatan rumah sakit, beberapa penelitian menunjukkan bahwa nyeri sering tidak dikelola dengan baik selama perawatan Rumah Sakit ${ }^{4}$.

Manajemen nyeri merupakan serangkaian pengaturan dalam menangani nyeri yang dialami pasien. Manajemen nyeri meliputi pengkajian nyeri, penatalaksanaan nyeri, intervensi nyeri, terapi nyeri, audit nyeri, edukasi terhadap tenaga kesehatan dan pasien, serta aktivitas lain dalam rangka memberikan perawatan dan pelayanan pada pasien yang mengalami nyeri ${ }^{5}$. Perawat mengambil sebagian besar tanggung jawab untuk manajemen nyeri selama rawat inap pasien ${ }^{6}$. Glowacki $(2015)^{7}$ menekankan bahwa penatalaksanaan nyeri yang adekuat merupakan persyaratan universal dan menarik dalam perawatan kesehatan. Penatalaksanaan nyeri dalam konteks manajemen nyeri yang optimal tidak dapat terlaksana tanpa diawali dengan pengkajian yang komprehensif ${ }^{7}$.

Proses pengkajian yang komprehensif harus dilakukan untuk mengidentifikasi bagaimana serangkaian faktor biomedis, psikososial, dan perilaku berinteraksi untuk mempengaruhi sifat, besarnya, ketahanan, dan respons pasien terhadap pengobatan ${ }^{8}$. Pengukuran nyeri yang memadai sangat penting untuk pengkajian dan penanganan nyeri ${ }^{9}$. Nyeri dapat dibedakan menjadi beberapa jenis, yaitu: berdasarkan onset, patologi yang mendasari, dan sumber nyeri. ${ }^{5,10}$ Berdasarkan onset, nyeri dibagi menjadi nyeri akut dan nyeri kronik. Kedua nyeri tersebut memiliki perbedaan dan membutuhkan skala pengukuran nyeri yang berbeda juga.

Selain disesuaikan dengan jenis nyeri yang dialami pasien, perawat juga perlu mempertimbangkan keadaan pasien. Berbagai contoh, diantaranya, pasien dengan penurunan kesadaran atau pasien dengan demensia tidak dapat menyampaikan nyeri secara verbal kepada perawat, seperti pada pasien dengan kesadaran yang baik. Berbagai alat pengukuran skala nyeri dibuat oleh banyak ahli, semuanya diujicobakan juga oleh peneliti untuk digunakan pada kelompok pasien tertentu pasien tertentu. Contoh skala nyeri behavior pain scale (BPS) dalam penelitian Dehghani et al (2014) $)^{11}$, bahwa BPS valid dan reliabel untuk digunakan pada pasien ICU dengan tingkat kesadaran rendah karena trauma kepala. Skala nyeri selanjutnya yaitu Visual Analog Scale (VAS), yang diketahui efektif untuk menilai nyeri akut pada pasien postoperasi sebelum dan sesudah pemberian analgesik dibandingkan dengan pengukuran skala nyeri numerik ${ }^{12}$.

Pemberian pengetahuan pada perawat sebagai pelaksana pengkajian nyeri perlu dilakukan. Perawat yang memiliki pengetahuan akan meningkatkan pelaksanaan pengkajian nyeri yang efisien. Kegiatan pelatihan 
pengkajian nyeri ini memberikan informasi dan edukasi pada perawat di Rumah Sakit tentang metode pengkajian nyeri beserta penerapannya pada pasien. Keberagaman metode pengkajian nyeri beserta pengukuran skala nyeri yang ada, selain dapat menambah pengetahuan, juga dapat menyebabkan kebingungan penggunaannya. Kebingungan penggunaan skala pengukuran nyeri dapat disebabkan kurang mendalamnya pengetahuan, sehingga pendalaman tersebut sangat diperlukan.

Manajemen nyeri yang tepat tergantung pada pengkajian nyeri yang sistematis. Nyeri seharusnya dikaji secara rutin dan terstruktur, tetapi hal ini seringkali tidak dilakukan. Tidak adekuatnya pengkajian nyeri dapat menyebabkan tidak dikenalinya masalah nyeri sehingga nyeri tidak tertangani. Nyeri yang tidak ditangani secara optimal dapat menimbulkan dampak negatif terhadap fungsi fisiologis diantaranya fluktuasi tanda-tanda vital, meningkatkan waktu rawat inap, dan dapat menimbulkan post traumatic stres disorder ${ }^{13}$. Nyeri seharusnya dikaji secara rutin dan terstruktur, tetapi hal ini seringkali tidak dilakukan Alat ukur pengkajian nyeri yang valid dan direkomendasikan telah tersedia, namun banyak perawat yang tidak menggunakannya ${ }^{14}$.

Rumah Sakit Universitas Brawijaya (RSUB) merupakan salah satu rumah sakit di Kota Malang yang menyelenggarakan kegiatan pelayanan kesehatan pada masyarakat. Agar dapat memberikan pelayanan prima dan optimal, maka RSUB harus dapat menerapkan keselamatan pasien di rumah sakit, termasuk melalui manajemen nyeri pada pasien. Berdasarkan hal tersebut maka perlu dilakukan pelatihan pengkajian nyeri pada perawat untuk mengoptimalkan upaya manajemen nyeri di RSUB Malang.

\section{Target dan Luaran}

Kegiatan pengabdian masyarakat ini dilaksanakan selama satu bulan, yakni sejak November sampai dengan Desember 2019. Tempat pelaksanaan kegiatan adalah Ruang Pertemuan Rumah Sakit Universitas Brawijaya, Kota Malang, Jawa Timur. Kegiatan ini diikuti oleh 63 perawat pelaksana dengan latar pendidikan D3 dan Ners yang aktif bekerja di berbagai unit di RSUB, diantaranya Ruang Intensive Care Unit (ICU), Instalasi Gawat Darurat (IGD), Kamar Operasi (KO), Ruang rawat intermediet, dan Rawat jalan. Setiap unit perawatan memiliki karakteristik pasien yang berbeda-beda, dimulai dari pasien yang mampu mengkomunikasikan nyerinya secara verbal maupun pasien yang tidak dapat menyampaikan nyeri yang dirasakan.

Luaran yang didapatkan adalah Modul Pengkajian Nyeri sebagai Pedoman yang dapat digunakan oleh perawat maupun mahasiswa keperawatan dalam melaksanakan pengkajian nyeri dalam tatanan perawatan di Rumah Sakit.

\section{Metodologi}

Kegiatan pengabdian masyarakat ini menggunakan metode Focus Group Discussion (FGD) dan pemberian materi tentang pengkajian nyeri dan penggunaanya dalam menyokong manajemen nyeri. Pada Focus Group Discussion (FGD), perawat dikelompokkan menjadi kelompok kecil dengan difasilitasi 1 orang fasilitator untuk memandu diskusi. Setiap kelompok membahas tentang pengkajian nyeri yang dilaksanakan oleh masing-masing unit kerja, perbedaan, serta alasan penggunaannya.

Pemberian materi selanjutnya diberikah pakar dan praktisi ahli yang membahas beberapa metode pengkajian nyeri, berbagai skala pengkajian nyeri dengan kelemahan dan kelebihannya.

Pengkajian nyeri terutama dapat menggunakan metode PQRST (Provoke/Palliation, Quality/Quantity, Region/ Radiation, Severe Score, Timing) dengan skala nyeri yang dapat digunakan pada pasien tanpa kendala dalam berkomunikasi dan skala nyeri pada pasien dengan gangguan komunikasi, seperti pada kasus pasien dengan gangguan kesadaran maupun gangguan kognitif lain. Pada akhir kegiatan, perawat sebagai peserta akan diberi buku panduan tentang pengkajian nyeri pada berbagai kondisi pasien. Rumah sakit dapat menggunakan buku panduan tersebut sebagai pedoman dalam pelaksanaan pengkajian di berbagai unit kerja RSUB.

Teknik pengumpulan data dilakukan dengan pre-test dan post-test. Pre-test digunakan untuk menggambarkan dan mengukur 
pengetahuan peserta tentang pengkajian nyeri sebelum mengikuti kegiatan pelatihan. Setelah diberikan materi, post-test digunakan untuk menggambarkan dan mengukur pengetahuan peserta tentang pengkajian nyeri setelah mengikuti kegiatan pelatihan. Data yang diperoleh kemudian dianalisis, dimulai dengan dideskripsikan secara naratif dan dianalisis dengan uji t-dependen dengan $p$ value $(p<0.05)$.

\section{Pembahasan}

Perawat pelaksana yang berperan dalam mendukung proses pengkajian nyeri di Rumah Sakit Universitas Brawijaya (RSUB) mayoritas lulusan dari program profesi Ners sebanyak 39 perawat $(61.9 \%)$, sisanya merupakan lulusan program pendidikan DIII Keperawatan sebanyak 24 perawat $(38.1 \%)$. Perawat pelaksana perempuan juga mendominasi sebanyak $76.19 \%$ (48 perawat) dibandingkan dengan perawat lakilaki sebanyak $23.81 \% \quad$ (15 perawat). Karakteristik perawat pelaksana yang berperan peting dalam pengkajian nyeri secara rinci dapat dilihat pada data Tabel 1.

Berdasarkan data dari Tabel 1, terlihat bahwa sebanyak $69.84 \%$ (44 perawat) berusia antara 26-35 tahun yang termasuk kedalam kelompok dewasa awal berdasarkan pengelompokkan usia oleh Depkes RI dan sebanyak $30.16 \%$ (19 perawat) termasuk kedalam kelompok usia remaja akhir. Perawat pelaksana berasal dari beberapa unit kerja, yaitu: 9 Perawat $(14.28 \%)$ di Intensive Care Unit (ICU), 11 perawat $(17.46 \%)$ di Kamar Operasi (OK), 22 Perawat (34.92\%) di Poliklinik (Rawat Jalan), 16 perawat $(25.4 \%)$ di Instalasi Gawat Darurat (IGD). Lama bekerja perawat pelaksana paling banyak termasuk dalam kategori lama bekerja 1-5 tahun sesuai dengan penelitian Ariyanti (2017), yaitu sebanyak 80.95\% (51 perawat dan perawat dengan lama bekerja lebih dari 5 tahun sebanyak 19.05 (12 perawat).

Karakteristik perawat yang dijelaskan pada tabel 1, beberapa penelitian mengaitkan dan memiliki hubungan bermakna dengan kinerja yang dilaksanakan oleh perawat tersebut. Robbins $(2008)^{15}$, menyatakan bahwa karakteristik individu seperti umur, masa kerja, dan status pernikahan dapat mempengaruhi kinerja individu. Penelitian Amriyati, et al
$(2003)^{16}$ menunjukkan bahwa Status pendidikan dan usia berhubungan dengan hasil kinerja yang baik. Penelitian tersebut menjabarkan bahwa peran pendidikan tinggi terhadap kinerja berkaitan dengan sebuah pernyataan bahwa, semakin tinggi pendidikan maka semakin membutuhkan tingkat intelektualitas yang tinggi dan pada akhirnya mempengaruhi kinerja16. Usia juga dikaitkan dengan kinerja yang baik juga dikarenakan, semakin bertambah usia maka semakin pegawai akan merasa senang dan nyaman sehinggi dapat memberikan kinerja yang baik.

Tabel 1. Karakteristik Perawat Pelaksana di RSUB

\begin{tabular}{|c|c|c|c|}
\hline No & $\begin{array}{l}\text { Karakteristik } \\
\text { Responden }(n=63)\end{array}$ & Jumlah & $\begin{array}{l}\text { Persentase } \\
(\%)\end{array}$ \\
\hline \multirow[t]{3}{*}{1} & \multicolumn{3}{|c|}{ Usia (Depkes RI, 2009) } \\
\hline & 20-25 tahun & 19 & 30.16 \\
\hline & 26-35 tahun & 44 & 69.84 \\
\hline \multirow[t]{3}{*}{2} & \multicolumn{3}{|l|}{ Jenis Kelamin } \\
\hline & Perempuan & 48 & 76.19 \\
\hline & Laki-laki & 15 & 23.81 \\
\hline \multirow[t]{3}{*}{3} & \multicolumn{3}{|l|}{ Pendidikan } \\
\hline & Ners & 39 & 61.9 \\
\hline & DIII Keperawatan & 24 & 38.1 \\
\hline \multirow[t]{6}{*}{4} & \multicolumn{3}{|l|}{ Unit Kerja } \\
\hline & $\begin{array}{l}\text { Intensive Care Unit } \\
\text { (ICU) }\end{array}$ & 9 & 14.28 \\
\hline & $\begin{array}{l}\text { Kamar Operasi } \\
(\mathrm{OK})\end{array}$ & 11 & 17.46 \\
\hline & Rawat Inap Biasa & 22 & 34.92 \\
\hline & $\begin{array}{l}\text { Poliklinik (Rawat } \\
\text { Jalan) }\end{array}$ & 5 & 7.94 \\
\hline & $\begin{array}{l}\text { Instalasi Gawat } \\
\text { Darurat (IGD) }\end{array}$ & 16 & 25.4 \\
\hline 5 & \multicolumn{3}{|c|}{ Lama Bekerja (Ariyanti, 2017) } \\
\hline & 1-5 Tahun & 51 & 80.95 \\
\hline & $\geq 5$ Tahun & 12 & 19.05 \\
\hline
\end{tabular}


Hasil penelitian yang dilakukan oleh Kumajas, et al (2014) ${ }^{17}$ menunjukan terdapat hubungan yang signifikan dari masing-masing karakteristik individu yaitu umur, pendidikan, masa kerja, dan status pernikahan dengan kinerja perawat secara umum dalam melaksanakan asuhan keperawatan di ruang rawat inap. Salah satu hasil penelitian ${ }^{17}$ Kumajas, et al $(2014)^{17}$ menunjukan adanya hubungan yang bermakna antara umur dengan kinerja perawat. Peneliti tersebut berpendapat bahwa, usia yang semakin meningkat akan meningkat pula kebijaksanaan kemampuan seseorang dalam mengambil keputusan, berpikir rasional, mengendalikan emosi, dan bertoleransi terhadap pandangan orang lain, sehingga berpengaruh terhadap peningkatan kinerjanya. Hasil penelitian yang juga menunjukan adanya hubungan yang bermakna antara lama bekerja dengan kinerja perawat. Peneliti tersebut beranggapan bahwa menunjukkan makin lama tenaga kerja bekerja, makin banyak pengalaman yang dimiliki tenaga kerja yang bersangkutan. Sebaliknya, makin singkat masa kerja, makin sedikit pengalaman yang diperoleh. Pengalaman bekerja banyak memberikan keahlian dan keterampilan kerja.

Kinerja dalam konteks penelitian ini adalah kinerja dalam melaksanakan pengkajian nyeri guna menyokong manajemen nyeri yang efektif. Sebelum menilai kinerja, pengetahuan sebagai salah satu faktor yang mendukung kinerja yang baik harus dinilai terlebih dahulu. Hal ini sesuai dengan penelitian yang dilakukan oleh Mailool, et al $(2017)^{18}$, yang menunjukkan bahwa terdapat hubungan antara pengetahuan dengan kinerja perawat pelaksana di Instalasi Rawat Inap RSU Pancaran Kasih GMIM Manado. Pentingnya pengetahuan sangatlah krusial dalam mendukung kinerja optimal yang dilakukan oleh perawat. Peningkatan pengetahuan menjadi sangat penting, sehingga perlu dilakukan berbagai upaya, diantaranya dengan memberikan pelatihan kepada perawat.

Hasil penelitian didapatkan bahwa ratarata nilai pengetahuan perawat tentang pengkajian nyeri sebelum dilakukan pelatihan yaitu $65.40 \pm 17.116$ (rentang nilai 0-100). Setelah diberikan pelatihan, pengetahuan perawat tentang pengkajian nyeri meningkat yaitu dengan rata-rata nilai $92.06 \pm 9.008$ (rentang 0-100). Hasil uji t-dependent (pre-test dan post-test one group) dengan nilai $\mathrm{p}<0.05$ menunjukkan nilai yang signifikan yaitu $p<0.05$ (0.03). Hasil penelitian dapat diamati secara rinci pada Tabel 2. Hasil tersebut menunjukkan bahwa pelatihan tentang pengkajian nyeri pada pasien dapat meningkatkan pengetahuan perawat tentang pengkajian nyeri. Pengetahuan yang baik dapat dijadikan bekal dalam melakukan pengkajian nyeri guna menunjang manajemen nyeri yang komprehensif.

Tabel 2. Pengetahuan perawat tentang pengkajian nyeri sebelum dan sesudah pelatihan pengkajian nyeri

\begin{tabular}{llll}
\hline No & $\begin{array}{l}\text { Hasil } \\
\text { Pengukuran } \\
\text { (rentang 0-100) }\end{array}$ & $\begin{array}{l}\text { Hasil Ukur } \\
\text { (Mean+SD) }\end{array}$ & $\begin{array}{l}\text { Nilap p } \\
\text { (Uji T- } \\
\text { dependent) }\end{array}$ \\
\hline 1 & $\begin{array}{l}\text { Pengetahuan } \\
\text { perawat sebelum } \\
\text { pelatihan }\end{array}$ & $65.40 \pm 7.116$ & 0.03 \\
2 & $\begin{array}{l}\text { Pengetahuan } \\
\text { Perawat sesudah } \\
\text { pelatihan }\end{array}$ & $92.06 \pm 9.008$ & \\
\hline
\end{tabular}

Hasil penelitian ini didukung dengan berbagai penelitian sebelumnya yang menunjukkan keefektikan pemberian pelatihan terhadap peningkatan pengetahuan, diantaranya yang dilakukan oleh Setyawati, et al $(2017)^{19}$ yang dilakukan pada sekelompok perawat dan bidan. Setyawati ${ }^{19}$, et al $(2017)^{19}$ menunjukkan bahwa terdapat pengaruh pelatihan tentang penerapan evidence-based practice terhadap peningkatan pengetahuan perawat dan bidan tentang konsep penerapan tersebut secara signifikan $(\mathrm{p}=0,000, \mathrm{p}<0.05)$. Pengetahuan yang didapat pada penelitian tersebut didukung oleh karakteristik perawat dan bidan yang meliputi riwayat pendidikan dan usia. Penelitian serupa yang dilakukan oleh Tiwow, et al $(2018)^{20}$ menerangkan bahwa pemberian pelatihan kepada perawat tentang manajemen pelaksanaan ronde keperawatan meningkatkan pengetahuan perawat tentang pelaksanaan proses tersebut.

Seperti yang sudah dijelaskan sebelumnya bahwa pengetahuan penting dalam menyokong kinerja yang baik. Kinerja yang baik dalam konteks ini adalah kinerja dalam melaksanakan pengkajian nyeri. Penelitian lain yang dilakukan oleh Simamora, et al (2017) ${ }^{21}$ yang menunjukkan 
bahwa pelatihan ronde keperawatan telah memberikan implikasi terhadap peningkatan Motivasi, maupun keterampilan perawat dalam pemberian asuhan keperawatan sehingga intervensi atau pelatihan ronde keperawatan menghasilkan kinerja perawat yang semakin baik dalam pemberian asuhan keperawatan. Penelitian ini belum menilai sejauh mana kinerja yang dilakukan oleh perawat setelah pelaksanaan pelatihan, namun penelitian ini sudah memberikan gambaran awal bahwa pelatihan berdampak baik dalam meningkatkan pengetahuan perawat yang dapat menjadi modal awal dalam mendukung pelaksanaan pengkajian nyeri yang baik.

\section{Kesimpulan}

Kegiatan pelatihan pada perawat tentang pengkajian nyeri pada pasien disesuaikan dengan kondisi pasien dapat meningkatkan pengetahuan perawat tentang pengkajian tersebut. Hal ini dibuktikan dengan meningkatnya nilai post-test perawat dibandingkan dengan nilai pre-test. Perawat diharapkan mampu melaksanakan pengkajian keperawatan diantaranya menggunakan skala nyeri yang tepat sesuai dengan kondisi pasien. Kepala ruangan sebagai manajer dalam suatu unit perawatan dapat mengambil alih dalam melakukan supervise terhadap pelaksaan pengkajian keperawatan yang tepat. Pengkajian nyeri yang tepat diharapkan dapat mendukung terlaksananya manajemen nyeri yang optimal di Rumah Sakit.

\section{Ucapan Terima Kasih}

Terima kasih kami ucapkan kepada segenap civitas akademika Universitas Brawijaya yang telah mendukung secara finansial kegiatan pengabdian masyarakat yang dilaksanakan di Rumah Sakit Universitas Brawijaya ini. Kami juga mengucapkan terima kasih kepada jurusan keperawatan khususnya yang senantiasa memberikan dukungan dan arahan dalam pelaksanaan dan pelaporan kegiatan pengabdian masyarakat tentang pelatihan pengkajian nyeri keperawatan ini. Semoga kegiatan ini dapat mendukung pelaksanaan manajemen nyeri yang efektif oleh perawat di Rumah Sakit Universitas Brawijaya.

\section{Daftar Pustaka}

[1] Ballantyne, JC, Fishman, SM, Rathmell, JP. 2019. Bonica's Management of Pain. Philadepia, United States of America (USA): Lippincolt William Wilkins-a Wolter Kluwer Bussines.

[2] Baratta, JL, Schwenk, ES, Viscusi, ER. 2014. Clinical consequences of inadequate pain relief: barriers to optimal pain management. Plast Reconstr Surg. Oct;134(4 Suppl 2):15S-21S. doi: 10.1097/PRS.0000000000000681.

[3] Komite Keselamatan Pasien Rumah Sakit (KKPRS). (2015). Pedoman Pelaporan Insiden Keselamatan Pasien (IKP). http://www.pdpersi.co.id/kanalpersi/. Diakses tanggal 13 Februari 2019.

[4] Cea, ME, Reid, MC, Inturrisi, C, Witkin, LR, Prigerson, HG, Bao, Y. 2016. Pain Assessment, Management, and Control Among Patients 65 Years or Older Receiving Hospice Care in the U.S. J Pain Symptom Manage. Nov;52(5):663-672. doi: 10.1016/j.jpainsymman.2016.05.020.

[5] Lellan, KM. 2006. Management of Pain: A Practical Approach for Health Care Professionals. Cheltenham, United Kingdom: Nelson Thornes Ltd.

[6] Chen, J, Lu, Q, Wu, XY, An, Y.Z., Zhan, YC, Zhang, HY. 2016. Reliability and validity of the Chinese version of the behavioral pain scale in intubated and nonintubated critically ill patients: Two crosssectional studies. International Journal of Nursing Studies, $26 \quad$ May, 61:63-71. doi.org/10.1016/j.ijnurstu. 2016.05.013.

[7] Glowacki, D. 2015. Effective pain management and improvements in patients' outcomes and satisfaction. Crit Care Nurse. Jun;35(3):33-41. doi: 10.4037/ccn2015440.

[8] Staats, PS, Wallace, MS. 2015. Management; Just the Facts. Philadepia, United States of America: McGraw-Hill Education.

[9] Gupta, R. 2014. Pain Management; Essential Topic for Examinations. London, United Kingdom (UK): Springer Inc.

[10] Wilson, SF, Giddens, JF. 2016. Health Assessment for Nursing Practice. Canada, North America: Elsevier.

[11] Dehghani, H, Tavangar, H, Ghandehari, A. 2014. Validity and Reliability of Behavioral Pain Scale in Patients with Low Level of Consciousness Due to Head Trauma Hospitalized in Intensive Care Unit. Arch Trauma Res. 2014 Mar; 3(1): e18608. Doi:10.5812/atr.18608.

[12] Myles, PS, Myles, DB, Galagher, W, Boyd, D, Chew, C, MacDonald, N, Dennis, A. 2017. Measuring acute postoperative pain using the visual analog scale: the minimal clinically important difference and patient acceptable symptom state. British Journal of 

Anaesthesia, $118 \quad$ (3): $424-9 . \quad$ doi:
10.1093/bja/aew466.

[13] Priambodo, AP, Ibrahim, K, Nursiswati. 2016. Pengkajian nyeri pada pasien kritis dengan menggunakan Critical Pain Observation Tool (CPOT) di Intensive Care Unit (ICU). Jurnal Keperawatan Padjadjaran, 4(2), 162-9.

[14] Rose, L, Smith, O, Gelinas, C, Haslam, L, Dale, C, Luke, E, et al. (2012). Critical care nurses pain assessment and management practices: A survey in Canada. Am J Crit Care,21(4), 251-9. doi: 10.4037/ajec2012611.

[15] Robbins, SP. 2008. Perilaku Organisasi. Edisi Duabelas. Jakarta, Indonesia: Penerbit Salemba Empat.

[16] Amriyati, Sumarni, Sutoto. 2003. Kinerja perawat ditinjau dari lingkungan kerja dan karakteristik individu. Jurnal Manajemen Pelayanan Kesehatan. Vol.5/No.1/2003.

[17] Kumajas, FW, Warouw, H, Bawotong, J. 2014. Hubungan karakteristik individu dengan kinerja perawat di ruang rawat inap penyakit dalam rsud datoe binangkang kabupaten bolaang mongondow. EJurnal Keperawatan. Vol 2, No 2 (2014).

[18] Mailool, CM, Pondaag, L, Lolong, J. 2017. Hubungan faktor personal dengan kinerja perawat pelaksana di instalasi rawat inap rsu pancaran kasih GMIM Manado. Journal Keperawatan (eKp) Volume 5 Nomor 1, Februari.

[19] Setyawati, A, Harun, H, Herliani, YK. 2017. Peningkatan pengetahuan perawat dan bidan tentang evidence-based practice melalui pelatihan penerapan evidence-based practice. Dharmakarya: Jurnal Aplikasi Ipteks untuk Masyarakat. Vol. 6, No. 1, Maret: $53-56$.

[20] Tiwow, S, Tandipajung, TR. 2018. Pengaruh pelatihan terhadap pengetahuan pelaksanaan ronde keperawatan di RSUD Maria Walanda Maramis Airmadidi. Buletin Sariputra, Juni Vol. 8 (2).

[21] Simamora, RH, Bukit, E, Purba, JM, Siahaan, J. 2017. Penguatan kinerja perawat dalam pemberian asuhan keperawatan melalui pelatihan ronde keperawatan $\mathrm{Di}$ Rumah Sakit Royal Prima Medan. Jurnal pengabdian kepada masyarakat. Volume 23 No. 2, April - Juni. 